DOI: https://doi.org/10.35387/ucj.2(2).2020.79-84

\title{
NADIIA POSTRYHACH
}

\section{FEATURES OF TEACHER TRAINING IN ITALY (THE END OF THE XX - THE BEGINNING OF THE XXI CENTURY)}

\begin{abstract}
The urgency of studying the European tools for ensuring the quality of pedagogical education is determined by the international recognition of the importance of vocational training and teacher's development, which led to a significant improvement and increase in the educational process quality in the pedagogical education institutions. The key role of teachers in the modernization of European education, which is determined by the framework of all legislative documents that define the essence of the modern educational policy of the EU is emphasized. This causes challenges for the national system of pedagogical education in the context of the implementation of the concept "New Ukrainian School" of the XXI century. In the article the European common directions of ensuring the quality of pedagogical education in the late XX - early XXI centuries and its influence on the modernization of the national system of pedagogical education are analyzed. It is proved, that the main directions of ensuring the quality of pedagogical education in the European countries and Ukraine are: teacher training for educational reform, consolidating the organizational structures in the field of professional development and rationalization of national systems of pedagogical education; improving the quality of teacher training and development; focusing on pan-European joint activities in the area of in-service training for educators. The author established that the key provisions of international and pan-European documents set out a joint program of action to improve the quality of pedagogical education. In this program teachers are considered as the main agents of change in implementing the panEuropean strategy for the development of education and training, developing the European space of pedagogical education and forming on this basis a global model of a modern teacher

Key words: global model of teacher, diversification, competence, qualification, education, pedagogical education, quality of education, historical and pedagogical experience.
\end{abstract}

\section{ОСОБЛИВОСТІ ПРОФЕСІЙНОЇ ПІДГОТОВКИ ВЧИТЕЛІВ В ІТАЛІЇ (КІНЕЦЬ XX - ПОЧАТОК ХХІ СТОЛІТТЯ)}

\begin{abstract}
Анотація. Актуальність дослідження європейського інструментарію забезпечення якості педагогічної освіти визначається міжнародним визнанням важливості професійної підготовки й розвитку вчителів, що призвело до суттєвого покращення й підвищення якості навчального процесу в закладах педагогічної освіти. З'ясовано ключову роль учителів у модернізації європейської освіти, що підкреслюється в рамках усіх фундаментальних документів, які визначають сутність сучасної освітньої політики ЄС. Це зумовлює виклики для вітчизняної системи педагогічної освіти у контексті реалізації конщепції «Нової української школи» ХХІ століття. Проаналізовано європейські спільні напрями забезпечення якості педагогічної освіти наприкінці XX - початку XXI століття та їх вплив на модернізацію вітчизняної системи педагогічної освіти. Доведено, що основними напрямами забезпечення якості педагогічної освіти у країнах європейської спільноти та Україні $\epsilon$ : підготовка педагогів до освітньої реформи, консолідація організаційних структур у сфері підвищення кваліфікації та раціоналізації національних систем педагогічної освіти; підвищення якості фахової підготовки та вдосконалення вчителів; зосередження уваги на загальноєвропейських спільних заходах у сфері підвищення кваліфікації освітян. 3'ясовано, що у ключових положеннях міжнародних та загальноєвропейських документів фактично закладено спільну програму дій щодо покращення якості педагогічної освіти, в якій вчителі розглядаються як основні агенти змін щодо впровадження загальноєвропейської стратегії розвитку освіти і навчання, розвиток європейського простору педагогічної освіти та формування на цій основі глобальної моделі сучасного вчителя.
\end{abstract}

Ключові слова: глобальна модель вчителя, диверсифікація, компетентність, кваліфікація, освіта, педагогічна освіта, якість освіти, історико-педагогічний досвід.

Introduction. The XXI century was declared by UNESCO to be a «century of education». Theorists and practitioners in different countries across the world are developing the idea of «Education for the XXI century», working out and correcting a new paradigm of education in order to adapt the educational sphere to the present reality (Volynets, 2013, p. 1). Thus the new requirements for the level of prospective teacher training determine the necessity for conducting a historical and comparative analysis with the aim of researching into different countries' policies on education, borrowing positive and avoiding negative as- 
pects of the educational reforms that have already been made... Therefore it is important to study peculiarities of organizing the higher pedagogical education in the most developed countries in the world, Italy in particular as one of the G-7 countries and a Bologna Process founder (Nelin, 2017).

The Aim of the Study is to identify peculiarities of professional teacher training in Italy and substantiate possibilities for adapting Italian progressive expertise in professional teacher training with the aim of improving the quality of pedagogical education in Ukraine to meet the standards set in the European educational space.

Theoretical Basis and Methods of Research. The main research method is the content analysis of literary sources, which made it possible to identify peculiarities of teacher training in Italy in the specified chronological period and to substantiate possibilities for adapting Italian progressive expertise with the aim of improving the quality of pedagogical education in Ukraine.

The issues of the history of higher pedagogical education system have been kept under review by Ukrainian and foreign scientists: N. Avsheniuk, V. Andrushchenko, V. Baidenko, O. Lavrinenko, V. Luhovyi, O. Kucheriavyi, O. Ohiyenko, L. Pukhovska, A. Sbruyeva, M. Soldatenko, H. Sotska, etc. For their part, N. Barbieri, M. Gatullo, M. Corda Costa, I. Kovalynska, Kh. Krychkovska, P. Kriazhev, R. Laporta, G. Luzzatto, U. Margiotta, Ye. Nelin, L. Pavoni, O. Poddubey, L. Romanyshyna, A. Stepaniuk, K. Kravets, G. Tacconi, M. Todeschini, I. Vannini, M. Gentile, etc gave the most attention to the problem of the development of higher and pedagogical education in Italy.

Results. Proficiency in teaching is recognized as a factor that is the most closely connected with school and influences the quality of school education. Therefore special attention is given to the policy, syllabus and practice in teacher training programmes throughout the world. In Italy teacher training was a weakest part of the education system for a long time. In recent years the Italian government has made different reforms to improve the initial pedagogical education and maintain both work and life of Italian teachers up to standard. It is assumed that the quality of the whole system is ensured by proficiency of people working in it. Some Italian research studies on prospective teachers' beliefs and practice are presented beginning with the review of international studies on changes in teaching. In order to provide guidance on training programmes and improve teaching methods in higher education it was analyzed in pedagogical education of kindergarten and primary school teachers how beliefs and practice are transformed. In secondary teacher training programmes subject knowledge prevailed for a long time (Tacconi, Vannini, \& Gentile, 2018).

Since the last decades of the XX century a reform of the education system has been actively promoted in Italy. This updating process primarily applies to the initial teacher training. Besides the necessity of following Bologna standards and general European trends in the development of education, fundamental changes in teacher training are stimulated by the social situation in Italy, extremely rapid development of science and engineering, the necessity of meeting challenges to civilization... Throughout history the universities of Italy had given attention to the academic training of a graduate as an expert in a particular field of knowledge rather than a teacher. In the second half of the XX century the prominent Italian educators (Maria Corda Costa, Mario Gatullo, Raffaele Laporta) began to focus on prospective teacher training. It was only in the late 1990s that significant changes in the strategy of universities' new activity - basic teacher training - became visible. Among protagonists of the reform were G. Luzzatto, U. Margiotta, L. Pavoni (Krychkovska, 2008, p. 217).

Ye. Nelin notes that at the end of the XX century a centralized teacher training system established at the time of fascism was still functioning in Italy. However, in the early 1990s the well-known Pedagogical Faculty (Facoltà di Magistero) was reorganized into the Faculty of Preparatory Education (Facoltà di Scienze della Formazione) that trained qualified specialists in the following fields: «General Pedagogy», «Care» and «Manage-ment». According to Act №341 of 19 November 1990 the newly established unit was to train students in the «Primary Education» field (Corso di Laurea in Scienze della Formazione Primaria (CLSFP)). However, this course training was opened only in 1998-1999, which, for the first time in the history of the Italian education 
system, launched university training of kindergarten teachers and class teachers (maestro). The course curriculum was presented at a level of four-year training divided into two equal stages with the total number of 180 credits. However, taking into consideration Bologna Process requirements and the transition to the «3+2» system the CLSFP course training term was increased to 5 years. While at the first stage training is given in psychology, sociology and fundamental pedagogical disciplines (educo-logy, history of educology, teaching methods, etc), the second stage is represented by specialized training in the «Preschool Education» and «Primary School» fields. During professional training students begin to put the acquired knowledge into practice in laboratories preparing for on-thejob training in kindergartens or primary schools. After on-the-job training in years 4-5 a student is to complete training by defending a project before a commission. The latter always includes inspectors from the Ministry for Education, Universities and Research (MIUR) who act as intermediaries between a university and the labour market and enter students' names into the public register of teachers (Graduatoria) on the basis of performance in training and defence of projects. According to data as of the beginning of 2015, the CLSFP course training of students was given by every largest university in a region that admitted students in number determined by MIUR depending on changes on the labour market in the region and what educational institutions offered. Every year they try to make the course curriculum balanced at the request of both subject-oriented specialists who take the position that the syllabus should include a large number of major subjects and specialists in cross training who tend to believe that the syllabus should be developed on the basis of pedagogy, psychology, didactics, anthropology and sociology (Nelin, 2015, p. 118-119).

The CLSFP course training and the specialized training for SSIS involve laboratory sessions and on-the-job training. A minimum of $10 \%$ and $20 \%$ of credits are allocated for laboratory sessions in the CLSFP course training and the specialized training for SSIS respectively. There are a minimum of $20 \%$ and $25 \%$ of credits for practical sessions, which also include periods of planning and control, in the CLSFP course training and the specialized training for SSIS respectively. The training provided for each semester covers a total of 250-300 hours. Each university develops its own syllabus of training that contains the following aspects of education: training courses, their division into content modules, types of training sessions with compulsory foreign language training, etc; determines in terms of credits the training load which covers the independent work of each of the envisaged activities (the total number of credits per student for one semester is 30 ); determines possible reductions in the duration of the CLSFP course and the specialized training for SSIS in accordance with the credits granted; defines the components of the general individual semester study plan of the student in accordance with the norm of the Decree of the Ministry for University Education, Scientific Research and Technology of 21 July 1997 (№245 considering full or part-time attendance). Final examinations in the syllabus mostly relate to the total volume of training activities (no more than three per semester). The CLSFP or SSIS diploma examination includes the defence of a paper that contains the materials obtained during on-the-job training and laboratory sessions (Krychkovska, 2008, p. 224).

Before 2000 the Italian system did not include the didactic training of prospective teachers; in fact, the courses focus mainly on the content of knowledge. The idea based on the system of pedagogical education was that «to know» also meant «to know how to teach». After the first experience of two-year specialization for a prospective secondary school teacher new annual initial teacher training courses were organized in 2011-2012. Recently adopted Act № 107/2015 defines a new system of teacher training and recruitment. In analyzing this development Italian scientists suggest giving special attention to the necessary balance between practical experience and theoretical knowledge as well as to what this research suggests for initial pedagogical education. The continuous professional development (CPD) for teachers is the core of the European strategy for improving the quality of education. High quality CPD is of the utmost importance for guaranteeing relevant knowledge and competences with efficiency in modern classes. The survey shows two models of professional development that take approaches to adult education based on support- 
ing effective and innovative teaching methods. One model is a two-tier system of training: the first tier is based on courses; the second tier is supported by facilitators. This approach aims to disseminate the use of cooperative learning in $\mathrm{K}-12$ classes. The other model suggests video recording to encourage development of pedagogical knowledge about one of highly effective factors in teaching and learning: formative feedback (Tacconi, Vannini, \& Gentile, 2018).

According to the survey of Italian teachers that was carried out in 1991, most of the teachers expressed dissatisfaction with their training, especially their overall training, specific teaching skills and expectations of changes in the content and structure. Further study (1999) confirmed the same dissatisfaction with the initial training. More than $50 \%$ of the teachers believed that social perception of their function was declining and that decline would continue in the future. The attitude was changing when the subject matter was professional development, and many believed that among the tools needed to change the trend was the constant updating. According to the Ministry for Public Instruction, more than $80 \%$ of the teachers took multiple training in professional development in the previous two years; $95 \%$ were trained in the academic year of 1997-1998. During the academic year of 1999-2000 the office of the Ministry for Teacher Training Coordination (Coordinamento della Formazione degli Insegnanti - CFI) established in 1998 introduced the scheme for monitoring and studying the professional development initiatives with a school center to provide the Ministry with feedback on teacher training needs and opportunities (Todeschini, 2003, c. 230).

Today, the universities of the Italian Republic have developed a fairly wide network of diverse courses in disciplines that teach intercultural dialogue based on the multicultural approach. For instance, at the University of Padua the Faculty of Humanities, Sociology and Cultural Heritage teaches the course in Language, Literature and Cultural Heritage for students in cycles 1-2. The objective of the course is to provide master's training in education, culture and global society... in which prospective teachers are to think critically about the global scenario of society development and pluralization of social and cultural structures as well as to build their personal principles, self-learning skills and psychological readiness for constant changes... This is an integrated course in pedagogy and sociology, and a student chooses a specialization in cycle 2. After graduation he has a wide range of professions to choose from. He can do not only the job of a teacher but also of a consultant, coordinator, carry out the monitoring and evaluation of educational activities. The training lasts 3 years... In cycle 1 the students are taught the following languages and literature: Italian, English, Polish, Russian, Hungarian, Greek, Spanish, Serbian, Dutch, Croatian, Portuguese Slovak, Slovenian, etc., as well as fundamentals of intercultural communication. In the cycle of sociological disciplines they are taught socioanthropological peculiarities of regions. Selected topics offered for study are: - respect for the culture of the country; - linguistic strategies of the regions; - language and tradition. Sessions are held in an integrative format, in the form of discussions and traiings. In cycle 2 for a master's degree the students are taught such courses as «Education, culture and global society», «Modern languages, intercultural communication and international cooperation», «Management of educational services», «World religions», «Historical and cultural heritage», «Communication stragies», «Cultural anthropology», «Ethnolinguistics»... Thus, the teacher training programme in the specialty «Modern languages and civiliizations» provides extrmely broad and deep knowledge of the theory of communication, without which it is impossible to imagine the work of a modern teacher. Such in-depth theoretical training is supported by seminars, discussions and other interactive learning activities that promote the development and consolidation of intecultural communication skills and competences (Kovalynska, 2018, p. 38).

There is also much attention given to inquiry-based pedagogical education. The Ark of Inquiry teacher training model and its schedule for Italy developed by the UNESCO Regional Bureau for Science and Culture in Europe, Venice (Italy), significantly differs from the «one-size-fits-all» courses in professional development which are known to have very limited effectiveness. This particular training programme is specifically designed to meet the objectives and needs of the project and contribute to the desired results. In order to 
conduct these trainings UNESCO established strategic cooperation with the Association of natural science teachers (Associazione Nazionale Insegnanti di Scienze Naturali ANISN), which is a teacher training institution qualified by the Ministry for Education, Universities and Research of Italy (MIUR). ANISN helped the project in various ways to achieve the creation of a community of natural science teachers, to choose places for training, and its involvement in the training provided an additional incentive for teachers to participate in the form of accreditation and certificates recognized by the Ministry. The training programme focuses on improving the capacity and professional development of participants for them to gradually become experts in Inquiry-Based Science Education (IBSE) and on using research activities supported by local, national networks of colleagues and experts. This is achieved by: 1) adapting the training model and resources to the Italian and local context. The training modules and materials have been translated into Italian and combined into separate brochures for three stages (teachers as learners, thinkers and reflective practitioners) in order that they can be easily understood and accessible to teachers; 2) adopting a pragmatic approach and creating a multi-tier system to support the development of teachers involved in the project; 3 ) localizing the Ark of Inquiry in three Italian regions that will serve as reference centres / communities of practice and will be the starting point for further dissemination processes; 4) creating a network of the Ark of Inquiry of school teachers and coaching teachers involving the teachers with basic and expert knowledge of IBSE; 5) supporting a dynamic system that uses feedback and results obtained from the training project to improve and develop consistent training courses.

These goals were formulated based on the results and recommendations of the pilot phase of the project in Italy taking into account the different backgrounds of teachers and their diversity of experience in the inquiry-based teaching approach. The organizations participating in the training programmes include a scientific research centre in Naples, a well-equipped school in Rosa and the laboratory of a research centre in Foligno. Their par- ticipation can result in the desired involvement of research centres, museums and schools in the Ark of Inquiry project, which is one of the main goals of the project. It should be noted that training courses will be designed and structured differently depending on the different regions at which the training programme is aimed. This is explained by the differences in the backgrounds of teachers and their experience in the inquiry-based teaching approach. In Naples teachers will be divided into two groups based on their experience in IBSE. For one group that has basic knowledge of the inquiry-based approach the training in Stages A and C (teachers as learners and reflective practitioners) will include the on-line environment, a training session offered in Stage B (teachers as thinkers). For the other group with good practices in IBSE the training session will focus on group discussion of resources, different training stages, specific teaching methods and on comparison with previous experience in order to improve IBSE. In future these teachers will also be multipliers of research- oriented natural science education. It is supposed that in Rosa and Foligno the training courses will be taught in Stages A and $\mathrm{B}$ during the trainings and the training for Stage $\mathrm{C}$ will be done online (Kravets, 2016).

Conclusions. To sum up, the historical and comparative analysis conducted with the aim of studying the educational policy in the area of pedagogical education in the Italian Republic enabled us to reveal peculiarities of Italian teacher training in the late XX - early XXI centuries. The study found that the professional training of teachers of different subjects is carried out on the basis of action-based, researchoriented, interdisciplinary, multicultural, pragmatic and technological approaches as well as approaches to adult education based on the support of effective and innovative teaching methods, etc. This, in our opinion, provides the foundation for a multi-tier system to support the continuous professional development of teachers. The obtained results can be used to create a system of monitoring and research on professional development initiatives to provide feedback to the Ministry for Education of Ukraine on the needs and opportunities for training teachers in Ukraine. 


\section{REFERENCES}

Volynets, K.I. (2013). Professional training of future primary school teacher in the conditions of lifelong pedagogical education at university. Kyiv: Borys Hrinchenko University of Kyiv.

Kovalynska, I.V. (2018). Multicultural teacher education in Italy. Journal «ScienceRise: Pedagogical Education, 2 (22), 37-40.

Krychkovska, H. (2008). Features of basic university teacher training in Italy (end of the XX - begining of the XXI century.). Bulletin of Lviv University. Pedagogical Series, 24, 217-224.

Nelin, Ye.V. (2015). Current trends in teacher training in Italy. In L.L. Tovazhnianskyi, \& O.H. Romanovskyi (Ed.), Problems and prospects of formation of the national humanitarian and technical elite (Issue 44 (48), pp. 117-124). Kharkiv: NTU "KhPI".

Nelin, E.V. (2017). Trends in the development of higher pedagogical education in Italy (end of the XX beginning of the XXI century.). (PhD materials). Uman State Pedagogical University.

Kravets, K. (2016). The Ark of Inquiry teacher training plan in Italy. AHHAA - Ark of Inquiry Newsletter, 3. URL: http://www.unesco.org/new/en/venice/about-this-office/single-view/news/the ark of inquiry teacher training plan in italy

Tacconi, G., Vannini, I., \& Gentile, M. (2018). Teacher Education in Italy: challenges and perspectives. URL: https://eera-ecer.de/previous-ecers/ecer-2018-bolzano/programme-and-central-events/eerasessions/teacher-education-in-italy-challenges-and-perspectives/

Todeschini, M. E. (2003). Teacher education in Italy: new trends. In B. Moo (Eds.), Institutional Approaches to Teacher Education within Higher Education in Europe: Current Models and New Developments (pp. 223-240). UNESCO-CEPES: Studies on Higher Education.

Надія Постригач, кандидат біологічних наук, старший науковий співробітник, старший науковий співробітник відділу зарубіжних систем педагогічної освіти і освіти дорослих Інституту педагогічної освіти і освіти дорослих імені Івана Зязюна НАПН України.

Nadiia Postryhach, PhD in Biology, Senior Research Staff, Senior Research Staff of the Department of Foreign Pedagogical and Adult Education Systems, Ivan Ziaziun Institute of Pedagogical and Adult Education of NAES of Ukraine.

E-mail: pnadegeda@ukr.net ORCID ID 0000-0002-5433-2938

Received: 08.10.2020

Accepted: 12.11 .2020 